\title{
Pengaruh Model Pembelajaran Directed Reading Thinking Activity (DRTA) Berbantuan Media Animasi Terhadap Kemampuan Membaca Pemahaman
}

\author{
Ni Putu Yulia Padma Dewi ${ }^{1 *}$, N. N. Ganing², I B G. S. Abadi ${ }^{3}$ \\ 1,2,3 Jurusan Pendidikan Guru Sekolah Dasar Universitas Pendidikan Ganesha Singaraja, Indonesia
}

\section{ARTICLEIN \\ $\mathrm{F} \mathrm{O}$ \\ Article history: \\ Received 19 May \\ 2018 \\ Received in revised \\ form \\ 18 June 2018 \\ Accepted 16 July \\ 2018 \\ Available online 28 \\ August 2018}

Kata Kunci:

DRTA, animasi,

kemampuan

membaca

pemahaman

Keywords:

DRTA,

animation,

reading

comprehe

nsion

ability

\begin{abstract}
A B S TR A K
Penelitian ini bertujuan untuk mengetahui perbedaan yang signifikan kemampuan membaca pemahaman antara kelompok yang dibelajarkan melalui model pembelajaran Directed Reading Thinking Activity (DRTA) berbantuan media animasi dengan kelompok yang dibelajarkan melalui pembelajaran konvensional pada siswa kelas IV SD Negeri Gugus Dewi Sartika Denpasar Timur tahun pelajaran 2017/2018. Jenis penelitian ini adalah eksperimen semu menggunakan desain rancangan kelompok nonekuivalen. Populasi dalam penelitian ini berjumlah 385 siswa kelas IV SD Negeri Gugus Dewi Sartika tahun pelajaran 2017/2018. Sampel dalam penelitian ini berjumlah 80 siswa yaitu 39 siswa kelas IV dari SD Negeri 10 Kesiman yang menjadi kelompok eksperimen dan 41 siswa kelas IV dari SD Negeri 3 Kesiman yang menjadi kelompok kontrol. Pemilihan sampel dalam penelitian ini menggunakan teknik random sampling. Data di analisis dengan menggunakan uji-t, yaitu Polled Varians. Hasil analisis data menunjukkan (thitung $=3,360>$ ttabel $=2,000$ ) berdasarkan taraf signifikansi $5 \%$ dan $\mathrm{dk}=$ $78(\mathrm{n} 1+\mathrm{n} 2-2)$. Berdasarkan hasil uji-t didukung oleh perbedaan nilai rata-rata kedua kelas dapat disimpulkan bahwa terdapat pengaruh model pembelajaran Directed Reading Thinking Activity (DRTA) berbantuan media animasi terhadap kemampuan membaca pemahaman siswa kelas IV SD Negeri Gugus Dewi Sartika Denpasar Timur tahun pelajaran 2017/2018.
\end{abstract}

\section{A B S T R A C T}

The purpose of this research was to determine significant differences of reading comprehension ability between the students learned by using DRTA (Directed Reading Thinking Activity) learning model assisted animation media and conventional learning model of the fourth grade students Gugus Dewi Sartika East Denpasar district academic year 2017/2018. This type of research was a quasiexperiment using a non-equivalent control group design. The research of the population were 385 elementary fourth grade students Gugus Dewi Sartika East Denpasar district academic year 2017/2018. The sample of this research were 80 students, 39 fourth grade students of SD Negeri 10 Kesiman as experiment group and 41 fourth grade students of SD Negeri 3 Kesiman as control group. Sample selection in this research using random sampling technique. The data analyzed by using statistical analysis t-test that has been used Polled Varians. The results of data analysis shows (tcount $=3,360>$ ttable $=2,000)$ in significantly $5 \%$ and $d k=78(n 1+n 2-2)$. Based on the results of t-test that support by differences in the average value of the two classes it can be conclude that there is an effect Directed Reading Thinking Activity (DRTA) learning model assisted animation media on reading comprehension ability fourth elementary grade students Gugus Dewi Sartika East Denpasar district academic year 2017/2018.

\footnotetext{
Corresponding author.

E-mail addresses: yuliapd13@gmail.com (Ni Putu Yulia Padma Dewi)
} 


\section{Pendahuluan}

Kebutuhan akan pendidikan menjadi salah satu hal yang tidak terelakkan pada setiap kehidupan manusia. Pendidikan merupakan pilar utama kemajuan suatu bangsa, karena salah satu hal penting untuk menciptakan sumber daya manusia yang unggul adalah melalui pendidikan. Menurut Undang-Undang No. 20 Tahun 2003 tentang Sistem Pendidikan menyatakan bahwa pendidikan adalah usaha sadar dan terencana untuk mewujudkan suasana belajar dan proses belajar agar peserta didik secara aktif mengembangkan potensi dirinya untuk memiliki kekuatan spiritual, keagamaan, pengendalian diri, kepribadian, kecerdasan, ahlak mulia serta keterampilan yang diperlukan dirinya, masyarakat, bangsa dan negara. Pendidikan berkaitan erat dengan segala sesuatu yang bertalian dengan perkembangan manusia mulai perkembangan fisik, keterampilan, pikiran, perasaan, dan kemauan social (Kusuma, 2014). Hal ini menunjukkan bahwa pembelajaran yang didesain guru harus berorientasi kepada aktivitas siswa dan memberikan pengertian pada pandangan dan penyesuaian bagi seseorang atau murid terdidik kearah kematangan dan kedewasaan (Anggreni, 2013).

Namun, di dalam dunia pendidikan sendiri terdapat berbagai permasalahan. Secara global, permasalahan pendidikan salah satunya adalah menghadapi tantangan globalisasi. Di era globalisasi dewasa ini telah terjadi pergeseran paradigma tentang keunggulan suatu negara, dari keunggulan komparatif yang bertumpu pada kekayaan sumber daya alam, menuju kepada keunggulan kompetitif bertumpu pada kepemilikan sumber daya manusia (SDM) yang berkualitas. Dalam konteks pergeseran paradigma keunggulan tersebut, pendidikan di Indonesia akan menghadapi permasalahan mengenai situasi kompetitif yang sangat tinggi, karena berhadapan dengan kekuatan pendidikan global. Saat ini Indonesia khususnya Bali, mengalami berbagai problematika pendidikan cukup banyak, mulai dari masalah kurikulum, kompetensi, kurangnya pemerataan sarana dan prasarana pendukung pembelajaran serta mutu SDM dalam pengelolaan pendidikan masih menjadi penyebab utama rendah kualitas pendidikan (Nasution, 2014). Maka, untuk menjawab tantangan globalisasi tersebut dibutuhkan sumber daya manusia yang berkarakter, handal, dan berdaya saing tinggi. Untuk mewujudkannya maka disinilah pendidikan harus menampilkan diri sebagai bagian dari tantangan globalisasi tersebut. Pendidikan ditantang harus mampu mendidik dan menghasilkan para lulusan yang berdaya saing tinggi agar dapat menunjang pembangunan di segala bidang.

Upaya peningkatan kualitas pendidikan terus dilakukan guna menciptakan SDM yang berkualitas. Dalam rangka menerapkan pendidikan yang berkualitas, pemerintah Indonesia telah menetapkan kurikulum 2013 untuk diterapkan di setiap sekolah. Peranan kurikulum dalam pendidikan sangatlah strategis dan menentukan pencapaian tujuan pendidikan nasional. Kurikulum memiliki kedudukan dan posisi yang sangat sentral dalam keseluruhan proses pendidikan, bahkan kurikulum merupakan syarat mutlak dan bagian yang tidak terpisahkan dari pendidikan. Pembelajaran kurikulum 2013 menekankan pembelajaran yang dapat mengantarkan siswa memiliki sikap ketakwaan dan karakter, keilmuan, dan kreativitas (Kurniawan, 2015). Pembelajaran kurikulum 2013 diharapkan mampu mengembangkan potensi siswa agar memiliki kemampuan hidup sebagai pribadi dan warga negara yang beriman, produktif, kreatif, inovatif, dan afektif serta mampu berkontribusi pada kehidupan masyarakat berbangsa, dan bernegara.

Proses pembelajaran pada Kurikulum 2013 untuk semua jenjang dilaksanakan dengan menggunakan pendekatan ilmiah (saintifik). "Pendekatan saintifik merupakan pendekatan di dalam kegiatan pembelajaran yang mengutamakan kreativitas dan temuan-temuan siswa" (Kosasih, 2014:72). Proses pembelajaran saintifik terdiri atas 5 pengalaman belajar pokok, yakni mengamati, menanya, mengumpulkan informasi/menalar, mengasosiasi, dan mengkomunikasikan atau yang lebih dikenal dengan 5M. Pada pelaksanaannya, kurikulum 2013 menggunakan sistem terintegrasi dengan menggunakan tema pada setiap pembelajarannya yang lebih dikenal dengan pembelajaran tematik terpadu. Penggunaan tema ini dimaksudkan untuk mengaitkan beberapa mata pelajaran ke dalam satu pokok pembahasan, sehingga pemisahan antar mata pelajaran tidak terlihat jelas.

Salah satu muatan materi yang termasuk ke dalam pembelajaran tematik kurikulum 2013 adalah bahasa Indonesia. Bahasa Indonesia memiliki peran sentral untuk mengembangkan intelektual, sosial, dan emosional siswa. Melalui kemampuan berbahasa siswa akan mampu mengungkapkan pikiran, mengekspresikan perasaan, dan dapat melaporkan fakta-fakta yang mereka amati. Keterampilan berbahasa Indonesia di SD mencakup: keterampilan mendengarkan, keterampilan berbicara, keterampilan membaca, dan keterampilan menulis. "Penyajian materi ke empat keterampilan berbahasa dilatarbelakangi oleh suatu kenyataan bahwa keterampilan berbahasa sangat penting dan bermanfaat dalam kehidupan sehari-hari" (Taufina, 2016:31). Dalam proses pembelajaran, keempat keterampilan berbahasa tersebut harus dilaksanakan secara seimbang dan terpadu, terlebih lagi pada keterampilan membaca. Kemampuan membaca menjadi hal yang penting dalam suatu masyarakat sebab melalui 
membaca dapat diserap berbagai informasi dan wawasan pengetahuan untuk mengembangkan peradaban masyarakat tersebut (Krismanto, 2015). Melalui kegiatan membaca memungkinkan seseorang untuk mampu mempertinggi daya pikirnya, mempertajam padangannya dan memperlu as wawasannya. Membaca menjadi kunci ilmu pengetahuan karena segala bentuk ilmu pengetahuan mayoritas disampaikan melalui sistem bahasa tulis (Kurniawan, 2015:38). Jika siswa memiliki kemampuan membaca yang terampil maka efek penguasaan siswa terhadap ilmu pengetahuan dari materi pembelajaran lain bisa tercapai. Untuk itu, kemampuan membaca menjadi kunci mutlak dalam pembelajaran.

Membaca pada siswa SD kelas rendah di mulai dari pengenalan huruf, yang merujuk pada menerjemahkan simbol tulis ke bunyi. Pada kelas tinggi keterampilan membaca merujuk pada memahami makna dari suatu bacaan. Memahami makna suatu bacaan membutuhkan kemampuan khusus yaitu membaca pemahaman. Membaca pemahaman dapat diartikan sebagai proses sungguh-sungguh yang dilakukan pembaca untuk memperoleh informasi, pesan, dan makna yang terkandung dalam sebuah bacaan. Kegiatan ini minimalnya akan melibatkan dua keterampilan dasar membaca yakni keterampilan visual dan keterampilan kognitif. Kedua keterampilan akan berperan secara timbal balik selama seseorang melakukan kegiatan membaca pemahaman. Mujaddid (2016) mengemukakan bahwa membaca pemahaman merupakan kegiatan untuk dapat memahami isi bacaan yang dibacanya.

Melalui membaca pemahaman, siswa dapat memperoleh informasi dan ilmu pengetahuan dalam proses pembelajaran. Namun kenyataannya, kesulitan memahami isi bacaan masih banyak dialami oleh siswa SD karena rendahnya minat baca siswa. Selain itu, sebagian siswa belum mengetahui tujuan kegiatan membaca yang mereka lakukan. Semakin kuat dan jelas tujuan aktivitas membaca yang dilakukan siswa maka akan semakin tinggi pula kemampuan memahami bacaan Hal ini merupakan tugas guru untuk mengarahkan siswa agar mengetahui tujuan dari aktivitas membaca yang mereka lakukan.

Hasil wawancara dan observasi yang dilakukan dengan guru kelas IV SD Negeri Gugus Dewi Sartika Denpasar Timur pada tanggal 10 Januari hingga 12 Januari 2018 menunjukkan bahwa siswa kelas IV SD Negeri Gugus Dewi Sartika Denpasar Timur masih kesulitan dalam kemampuan membaca pemahaman. Rendahnya kemampuan siswa dalam membaca pemahaman dibuktikan dengan: (1) siswa kesulitan dalam menentukan unsur intrinsik suatu bacaan, (2) siswa bingung dalam menentukan ide pokok dalam setiap paragraf, dan (3) siswa kesulitan dalam menyimpulkan apa yang dibacanya dengan kata-kata sendiri. Terdapat beberapa fakta dalam kegiatan pembelajaran yang menjadi penyebab rendahnya kemampuan membaca pemahaman, diantaranya: (1) siswa kurang berkonsentrasi atau fokus terhadap bacaan, (2) siswa belum mengetahui tujuan aktivitas membaca yang dilakukan, (3) bahan bacaan atau buku-buku yang digunakan dalam pembelajaran kurang menarik dan lengkap, (4) antusias, motivasi, dan semangat siswa dalam membaca masih kurang, dan (5) siswa kurang diikutsertakan dalam berkomunikasi dan berkontribusi dalam kegiatan pembelajaran.

Berdasarkan kondisi tersebut, perlu diadakan pembaharuan pembelajaran yang dilaksanakan di kelas. Guru hendaknya merancang pembelajaran sedemikian rupa sehingga proses pembelajaran di kelas dapat berlangsung dengan baik. Guru memiliki peran yang sangat penting untuk menciptakan model pembelajaran yang dapat melibatkan kontribusi siswa dan menuntut siswa aktif dalam pembelajaran, mulai dari perencanaan maupun dalam penggunaan media pembelajaran untuk meningkatkan kemampuan membaca pemahaman siswa. Selain itu, kegiatan pembelajaran diarahkan agar siswa mampu untuk berpikir, bekerja secara intelektual, dan menggunakan pengalaman serta pengetahuan yang dimilikinya secara optimal. Salah satu model pembelajaran yang dapat digunakan adalah model pembelajaran Directed Reading Thinking Activity (DRTA). Menurut Toliban (dalam Rofikasari, 2016:14) model pembelajaran Directed Reading Thinking Activity (DRTA) merupakan suatu aktivitas pemahaman yang meramalkan cerita hingga dapat membantu siswa untuk memperoleh gambaran keseluruhan dari suatu materi yang sudah dibacanya. Siswa ditugaskan untuk memberikan prediksi tentang apa yang akan terjadi dalam suatu teks, kemudian dalam membuat prediksi siswa menggunakan latar belakang pengetahuan yang dimilikinya tentang topik yang akan dibahas. Pada penelitian ini, model pembelajaran Directed Reading Thinking Activity (DRTA) akan dipadukan dengan menggunakan media animasi, karena media animasi pembelajaran akan menjadi lebih bermakna. Brown et al (dalam Susanto, 2014) menjelaskan kelebihan khusus dari penggunaan animasi ini yaitu dapat menghadirkan berbagai peristiwa dalam kontinuitas untuk memberikan pengalaman visual khusus dalam rangka pemahaman yang lebih mendalam. Serta, dengan adanya media pengajaran yang digunakan guru dapat mengkonkretkan konsepkonsep abstrak yang ada dalam materi pelajaran.

Berdasarkan paparan di atas dapat disimpulkan bahwa model pembelajaran Directed Reading Thinking Activity (DRTA) berbantuan media animasi merupakan model pembelajaran untuk mengembangkan kemampuan membaca pemahaman siswa secara kritis dan reflektif berupa merumuskan pertanyaan tentang teks, membuat prediksi, dan membuat keputusan berdasarkan 
informasi yang diperoleh dari membaca, dimana dalam penerapannya menggunakan media animasi untuk menggambarkan pikiran yang ingin disampaikan oleh penulis serta membantu membentuk pemahaman siswa dari berbagai konsep yang abstrak menjadi lebih konkret.

Berkaitan dengan hal tersebut, maka dilakukan penelitian dengan tujuan mengetahui perbedaan yang signifikan kemampuan membaca pemahaman antara kelompok siswa yang dibelajarkan melalui model pembelajaran Directed Reading Thinking Activity (DRTA) berbantuan media animasi dengan kelompok siswa yang dibelajarkan melalui pembelajaran konvensional pada siswa kelas IV SD Negeri Gugus Dewi Sartika Denpasar Timur tahun pelajaran 2017/2018

\section{Metode}

Jenis penelitian yang dilakukan dalam penelitian ini adalah penelitian kuantitatif dengan desain eksperimental yaitu quasi eksperiment (Eksperimen Semu), mengingat pemilihan subjek penelitian, tidak selalu dapat dilakukan secara random (individual random). Dalam penetapan random (random assignment), tidak memungkinkan memilih dan memilah subjek sesuai dengan rancangannya. Akan tetapi, terpaksa harus menerima kelas atau kelompok subjek yang telah ditentukan oleh sekolah, sesuai dengan kebijakan (Setyosari, 2015). Rancangan penelitian yang digunakan adalah rancangan non-ekuivalen yaitu menggunakan dua kelompok kelas. Kelas pertama merupakan kelas yang mendapat perlakuan model pembelajaran Directed Reading Thinking Activity (DRTA) berbantuan media animasi. Kelas kedua merupakan kelas kontrol.

\begin{tabular}{|llll|}
\hline $\mathrm{O}_{1}$ & $\mathrm{X}$ & $\mathrm{O}_{2}$ & (eksperimen) \\
\hdashline $\mathrm{O}_{3}$ & & $\mathrm{O}_{4}$ & (kontrol) \\
& & & \\
\hline
\end{tabular}

(Sumber : Setyosari, 2015:211)

\section{Gambar 1. Desain Eksperimen Menggunakan Rancangan Kelompok Non-ekuivalen}

Suatu penelitian dikatakan valid apabila hasil yang diperoleh disebabkan oleh variabel bebas yang dimanipulasi dan hasilnya dapat diberlakukan pada populasi penelitian. oleh karena itu, untuk meyakinkan bahwa hasil eksperimen benar-benar sebagai akibat pemberian perlakuan, dilakukan pengontrolan validitas internal maupun validitas eksternal. Validitas internal menyangkut tingkat kualitas ketepatan pengendalian aspek fisik-psikologis pelaksanaan penelitian dan pemilihan/penggunaan berbagai instrumen dalam pelaksanaan suatu penelitian Validitas eksternal penelitian mengacu pada sejauh mana suatu hasil penelitian dapat digeneralisasikan pada populasinya (Dantes, 2017). Populasi adalah kumpulan dari keseluruhan objek yang memiliki karakteristik tertentu yang ingin diteliti oleh peneliti lalu dipelajari dan ditarik kesimpulan. Populasi dari penelitian seluruh kelas IV SD Negeri Gugus Dewi Sartika Denpasar Timur tahun pelajaran 2017/2018 yang berjumlah 385 dan terdiri dari 12 kelas. Sampel adalah bagian dari populasi yang mewakili anggota populasi yang akan diteliti. Teknik pengambilan sampel pada penelitian ini adalah Random Sampling yang diacak adalah kelas, sehingga setiap kelas mendapatkan peluang yang sama untuk menjadi sampel penelitian. Dari 6 sekolah dasar yang ada di Gugus Dewi Sartika Denpasar Timur dilakukan pengundian untuk menentukan sekolah yang akan dijadikan sampel. Pemilihan sampel penelitian ini tidak dilakukan pengacakan individu melainkan hanya pengacakan kelas. Karena peneliti tidak bisa mengubah kelas yang telah terbentuk sebelumnya. Kelas dipilih sebagaimana telah terbentuk tanpa campur tangan peneliti.

Untuk mendapatkan kelas yang setara dari segi akademik, maka dipilih kedua kelas yang muncul saat undian diberikan pretest untuk menentukan kesetaraan. Nilai atau skor dari hasil pretest yang dilakukan tersebut digunakan untuk penyetaraan kedua kelas yang telah menjadi sampel. Untuk penyetaraan kelas, nilai atau skor dari hasil pretest dianalisis menggunakan uji t. Sebelum uji kesetaraan menggunakan uji t, maka data hasil pretest diuji prasyarat yaitu uji normalitas dan uji homogenitas. Jika skor pretest diperoleh memenuhi prayarat uji normalitas dan uji homogenitas maka dianalisis menggunakan uji t. Kesetaraan sampel di uji dengan rumus uji t yakni dengan polled varian. Selanjutnya, Pengundian tahap kedua untuk menentukan kelompok eksperimen dan kelompok kontrol. kelas yang muncul pertama saat diundi dijadikan sebagai kelompok eksperimen, sedangkan kelas yang muncul kedua dijadikan sebagai kelompok kontrol. Berdasarkan hasil undian, diperoleh kelas IV SDN 10 Kesiman berjumlah 39 siswa yang muncul pertama dijadikan sebagai kelompok eksperimen dan kelas IV SDN 3 Kesiman berjumlah 41 siswa yang muncul kedua dijadikan sebagai kelompok kontrol. 
Metode yang digunakan dalam pengumpulan data penelitian ini adalah metode tes. "Tes adalah cara memperoleh data yang berbentuk suatu tugas yang harus dikerjakan oleh seorang atau sekelompok orang yang dites (testee), dan dari tes dapat menghasilkan suatu skor (interval)" (Agung, 2014:92). Pada umumnya, metode tes banyak digunakan untuk mengukur ranah atau domain kognitif. Data yang dianalisis dalam penelitian ini adalah data kemampuan membaca pemahaman, untuk memperoleh data tersebut maka digunakanlah instrumen tes kemampuan membaca pemahaman. Tes ini disusun sendiri berdasarkan indikator-indikator dalam muatan materi Bahasa Indonesia pada.tema 8 Daerah Tempat Tinggalku. Tes objektif bentuk pilihan ganda biasa ini meliputi 4 pilihan jawaban (a, b, c atau d). Instrumen penelitian sebelum diujikan, dilakukan validasi teoretik terlebih dahulu kemudian dilakukan uji coba sebanyak 50 butir soal. Setelah uji coba soal tersebut dianalisis validitas butir, reliabilitas, tingkat kesukaran dan daya bedanya. Banyak butir tes yang memenuhi syarat pada uji coba tersebut sebanyak 34 butir tes. Analisis data yang digunakan adalah analisis statistik. Analisis statistik yang digunakan dalam penelitian adalah analisis statistik deskriptif dan analisis statistik inferensial. . Data yang digunakan untuk menganalisis adalah data gain skor yang dinormalisasikan dari hasil pretest dan posttest. Analisis statistik deskriptif digunakan untuk mendeskripsikan data pada kelompok eksperimen dan kelompok kontrol. Sugiono (2017:147) menyatakan, "statistik deskriptif adalah statistik yang digunakan untuk menganalisis data dengan cara mendeskripsikan atau menggambarkan data yang telah terkumpul". Dalam penelitian ini, data dideskripsikan dengan rata-rata atau mean, standar deviasi dan varians. Sedangkan untuk analisis statistik inferensial digunakan untuk menguji kebenaran hipotesis penelitian. "Statistik inferensial adalah teknik statistik yang digunakan untuk menganalisis data sampel dan hasilnya diberlakukan untuk populasi" (Sugiyono, 2017:148). Analisis data yang dilakukan adalah uji hipotesis menggunakan uji t. sebelum dilakukan uji hipotesis menggunakan uji t maka dilakukan uji prasyarat analisis yang berupa uji normalitas sebaran data tiap kelompok dan uji homogenitas varians antar kelompok.

\section{Hasil dan Pembahasan}

Deskripsi data kemampuan membaca pemahaman memaparkan nilai rata-rata, standar deviasi, varians, gain skor minimum dan gain skor maksimum. Pengolahan data dikerjakan dengan bantuan program pengolah angka Microsoft Office Excel 2016. Hasil deskripsi data kemampuan membaca pemahaman siswa kelas IV SD Gugus Dewi Sartika tahun pelajaran 2017/2018 dapat dilihat pada Tabel 1 berikut ini.

Tabel 1. Deskripsi Data Kemampuan Membaca Pemahaman

\begin{tabular}{lcc}
\hline \multicolumn{1}{c}{ Hasil Analisis } & Kelompok Eksperimen & Kelompok Kontrol \\
\hline Mean & 0,40 & 0,29 \\
\hline Standar Deviasi & 0,15 & 0,14 \\
\hline Varian & 0,02 & 0,02 \\
\hline Gain Skor Minimum & 0,08 & 0,05 \\
\hline Gain Skor Maksimum & 0,73 & 0,56 \\
\hline
\end{tabular}

Penjabaran mengenai distribusi frekuensi data gain skor kemampuan membaca pemahaman kelompok eksperimen dapat dilihat pada Gambar 2. Histogram Distribusi Frekuensi Gain Skor Ternormalisasi Kemampuan Membaca Pemahaman Kelompok Eksperimen berikut ini.

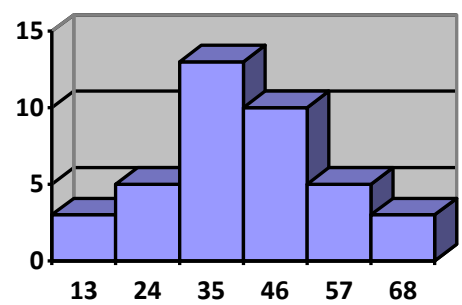

Gambar 2. Histogram Distribusi Frekuensi Gain Skor Ternormalisasi Kemampuan Membaca Pemahaman Kelompok Eksperimen 
Sedangkan penjelasan mengenai distribusi frekuensi data gain skor kemampuan membaca pemahaman kelompok kontrol dapat dilihat pada Gambar 3. Histogram Distribusi Frekuensi Gain Skor Ternormalisasi Kemampuan Membaca Pemahaman Kelompok Kontrol berikut ini.

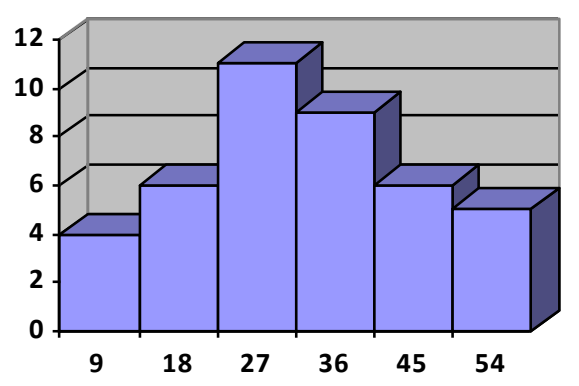

Gambar 3. Histogram Distribusi Frekuensi Gain Skor Ternormalisasi Kemampuan Membaca Pemahaman Kelompok Kontrol

Berdasarkan deskripsi data kemampuan membaca pemahaman kelompok eksperimen dan kelompok kontrol diperoleh rata-rata kelompok eksperimen lebih baik dibandingkan rata-rata kelompok kontrol. Rerata kemampuan membaca pemahaman siswa kelompok eskperimen $X=0,40>X=0,29$ rerata kemampuan membaca pemahaman siswa kelompok kontrol Sebelum dilakukan pengujian hipotesis terlebih dahulu dilakukan uji prasyarat yang meliputi uji normalitas dan uji homogenitas. Uji Normalitas dimaksudkan untuk mengetahui apakah sebaran data kemampuan membaca pemahaman siswa masingmasing kelompok berdistribusi normal atau tidak sehingga dapat menentukan teknik analisis datanya. Uji normalitas sebaran data dilakukan dengan menggunakan rumus analisis Kolmogorov Smirnov, Berdasarkan hasil uji normalitas sebaran data kelas eksperimen, diperoleh harga nilai maksimum |FT-FS| sebagai angka penguji normalitas, yaitu 0,0389. Harga tersebut kemudian dibandingkan dengan harga nilai tabel Kolmogorov-Smirnov untuk taraf signifikansi $5 \%(\alpha=0,05)$ dan $\mathrm{N}=39$, sehingga diperoleh harga nilai tabel Kolmogorov-Smirnov, yaitu 0,2178. Oleh karena Harga nilai maksimum $\mid$ FT-FS $\mid=0,0389$ $<$ harga nilai tabel Kolmogorov-Smirnov $=0,2178$, maka Ho diterima dan sebaran data gain skor ternormalisasi kemampuan membaca pemahaman kelompok eksperimen berdistribusi normal. uji normalitas sebaran data kelas kontrol, diperoleh harga nilai maksimum $|\mathrm{FT}-\mathrm{FS}|=0,0491$ sehingga angka penguji normalitas, yaitu 0,0491. Harga tersebut kemudian dibandingkan dengan harga nilai tabel Kolmogorov-Smirnov untuk taraf signifikansi $5 \%(\alpha=0,05)$ dan $\mathrm{N}=41$, sehingga diperoleh harga nilai tabel Kolmogorov-Smirnov, $=0,2125$. Oleh karena Harga nilai maksimum $\mid$ FT-FS $\mid=0,0491<$ harga nilai tabel Kolmogorov-Smirnov $=0,2125$, maka Ho diterima dan sebaran data gain skor ternormalisasi kemampuan membaca pemahaman kelas kontrol berdistribusi normal Uji homogenitas varian dilakukan berdasarkan data kemampuan membaca pemahaman kelompok eksperimen dan kelompok kontrol. Uji homogenitas varian menggunakan uji $\mathrm{F}$. Kriteria pengujian jika harga $F_{\text {hitung }}<$ harga $F_{\text {tabel }}$ maka sampel homogen. Pengujian dilakukan dengan taraf signifikansi 5\% dengan derajat kebebasan untuk pembilang $\mathrm{n}_{1}-1=(39-1=38)$ dan derajat kebebasan untuk penyebut $\mathrm{n}_{2}-1=(41-1=40)$. Sedangkan dari hasil perhitungan $F_{\text {hitung }}=1,26$, karena $F_{\text {hitung }}=1,26<F_{\text {tabel }}=1,70$ maka data Kemampuan membaca pemahaman mempunyai varians yang homogen. Dari hasil uji prasyarat yaitu uji normalitas sebaran data dan homogenitas diperoleh bahwa data kedua kelompok berdistribusi normal dan varians kedua kelompok homogen, maka uji statistik yang digunakan dalam penelitian ini adalah uji t dengan rumus polled varians. Dengan kriteria pengujian adalah jika harga $t_{\text {hitung }} \leq t_{\text {tabel }}$ maka Ho diterima dan Ha ditolak namun, jika harga $t_{\text {hitung }}>t_{\text {tabel }}$ maka Ho ditolak dan Ha diterima. Pada taraf signifikansi $5 \%$ dengan $\mathrm{dk}=\mathrm{n}_{1}+\mathrm{n}_{2}-2$. Dari hasil perhitungan diperoleh $\mathrm{t}_{\text {hitung }}=3,360$ karena nilai $t_{\text {hitung }}=3,360>\mathrm{t}_{\text {tabel }} \mathrm{l}=2,000$ sehingga Ho ditolak dan Ha diterima. Ini berarti terdapat perbedaan yang signifikan kemampuan membaca pemahaman kelompok eksperimen dan kelompok kontrol.

Berdasarkan simpulan uji hipotesis terdapat perbedaan yang signifikan kemampuan membaca pemahaman antara kelompok yang dibelajarkan melalui model pembelajaran Directed Reading Thinking Activity (DRTA) berbantuan media animasi dengan kelompok yang dibelajarkan melalui pembelajaran konvensional pada siswa kelas IV SD Negeri Gugus Dewi Sartika Denpasar Timur tahun pelajaran 2017/2018. Perbedaan yang signifikan kemampuan membaca pemahaman antara kelompok kontrol dan eksperimen terjadi akibat perlakukan yang berbeda antara kelompok kontrol dan kelompok eksperimen. Pada kelompok eksperimen siswa dibelajarakan dengan model pembelajaran Directed Reading Thinking Activity (DRTA) berbantuan media animasi. Pembelajaran dengan menggunakan model pembelajaran 
Directed Reading Thinking Activity (DRTA) berbantuan media animasi memiiki beberapa keunggulan. Merurut Taufina (2016:189) yang menyatakan keunggulan dari model pembelajaran Directed Reading Thinking Activity (DRTA) yakni, (1) memfokuskan keterlibatan siswa dengan teks, karena siswa memprediksi dan membuktikannya ketika mereka membaca, dan (2) mendorong siswa mengaplikasikan keterampilan metakognitif, karena siswa berfikir sesuai dengan jalan pikiran mereka sendiri. Kelas eksperimen dalam pembelajaran selama penelitian memanfaatkan media animasi untuk memperoleh informasi mengenai materi yang dipelajari yaitu materi bahasa Indonesia unsur intrinsik, siswa memanfaatkan media animasi untuk membentuk pemahaman siswa dari berbagai konsep cerita yang abstrak menjadi lebih konkret. Setelah siswa mengamati media animasi, siswa merumuskan pertanyaan tentang teks, membuat prediksi, dan membuat keputusan berdasarkan informasi yang diperoleh dari membaca. Berbeda halnya dengan kelas kontrol, proses pembelajaran dilakukan dengan cara menyampaikan materi kepada siswa setelah itu siswa diminta untuk menemukan informasi yang berada pada buku siswa. Langkah selanjutnya dilanjutkan dengan tanya jawab kemudian diikuti dengan pemberian tugas secara individu. Dengan pembelajaran seperti ini, siswa mempunyai kesempatan untuk mengembangkan kemampuan dan memperoleh informasi yang lebih banyak.

Hasil penelitian ini diperkuat oleh penelitian Sucitayana (2014) yang menyatakan bahwa model pembelajaran DRTA berpengaruh terhadap kemampuan membaca pemahaman literal siswa kelas V SD Negeri Gugus III Kecamatan Sukawati. Implikasi dalam penelitian adalah sebagai berikut. model pembelajaran Directed Reading Thinking Activity (DRTA) berbantuan media animasi dapat digunakan oleh guru dalam pembelajaran khususnya pembelajaran kemampuan membaca pemahaman dalam bahasa Indonesia, karena sudah terbukti bahwa model pembelajaran Directed Reading Thinking Activity (DRTA) berbantuan media animasi dapat mempengaruhi kemampuan membaca pemahaman siswa menjadi lebih baik. Dengan digunakannya model pembelajaran Directed Reading Thinking Activity (DRTA) berbantuan media animasi dalam pembelajaran, membuat pembelajaran menjadi lebih menarik, menyenangkan, dan tidak menoton. Hal ini dikarenakansiswa lebih aktif dan lebih tertarik dalam mengikuti pembelajaran, serta menumbuhkan rasa ingin tahu siswa tentang suatu cerita atau bacaan. Selain itu, hasil penelitian juga membuktikan bahwa model pembelajaran Directed Reading Thinking Activity (DRTA) berbantuan media animasi menciptakan suasana kelas yang menyenangkan, siswa menjadi lebih antusias dan termotivasi dalam mengikuti proses pembelajaran.

\section{Simpulan dan Saran}

Berdasarkan hasil analisis data kemampuan membaca pemahaman pada kelompok eksperimen, diketahui bahwa $\mathrm{X}=0,40$ dengan perolehan nilai gain skor minimum 0,08 dan nilai gain skor maksimum 0,73 . Berdasarkan hasil analisis data kemampuan membaca pemahaman pada kelompok kontrol, diketahui bahwa $X=0,29$ dengan perolehan nilai gain skor minimum 0,05 dan nilai maksimum 0,56. Berdasarkan hasil analisis data diperoleh thitung sebesar 3,360 Harga tersebut kemudian dibandingkan dengan harga ttabel. Harga ttabel diperoleh dari tabel nilai-nilai dalam distribusi t dengan derajat kebebasan $(\mathrm{dk}=39+41-2=78)$, pada taraf signifikansi $5 \%$. Berdasarkan tabel nilai-nilai dalam distribusi t diperoleh harga ttabel sebesar 2,000. Karena thitung $>\operatorname{ttabel}(3,360>2,000)$ maka Ho ditolak. $\mathrm{Hal}$ ini berarti terdapat perbedaan yang signifikan kemampuan membaca pemahaman kelompok siswa yang dibelajarkan melalui model pembelajaran Directed Reading Thinking Activity (DRTA) berbantuan media animasi dan kelompok siswa yang dibelajarkan tidak melalui model pembelajaran Directed Reading Thinking Activity (DRTA) berbantuan media animasi pada siswa kelas IV SD Negeri Gugus Dewi Sartika Denpasar Timur tahun pelajaran 2017/2018. Jadi dapat disimpulkan model pembelajaran Directed Reading Thinking Activity (DRTA) berbantuan media animasi berpengaruh terhadap kemampuan membaca pemahaman siswa kelas IV SD Negeri Gugus Dewi Sartika Denpasar Timur tahun pelajaran 2017/2018.

Berdasarkan hasil penelitian ini, maka dapat dikemukakan beberapa saran kepada guru, sekolah, dan peneliti lain. Agar hasil belajar Bahasa Indonesia khususnya membaca pemahaman siswa optimal dalam pembelajaran, guru hendaknya dapat menerapkan model pembelajaran Directed Reading Thinking Activity (DRTA) berbantuan media animasi sebagai alternatif dalam membelajarkan siswa di kelas. Sedangkan untuk menunjang proses pembelajaran agar siswa bisa lebih termotivasi untuk belajar pihak sekolah hendaknya menyediakan sarana dan prasarana yang maksimal. Sementara untuk mengetahui kemungkinan hasil yang berbeda pada pokok bahasan lainnya, disarankan kepada peneliti selanjutnya untuk melakukan penelitian yang sejenis pada pokok bahasan yang lain. 


\section{Daftar Rujukan}

Adawiyah, Rabiatul, Ali Karim dan Yunidar. 2017. Peningkatan Kemampuan Membaca Pemahaman Melalui Metode Diskusi Siswa Kelas IV SDN Inti Tomoli. Jurnal Kreatif Tadulako Online Vol. 5 No. 3.

Agung, A. A. G. 2014. Buku Ajar Metodelogi Penelitian Pendidikan. Malang: Aditya Media Publishing.

Anggreni, K. Putri, AAIN. Marhaeni, G. R. Dantes. 2013. pengaruh strategi directed reading thinking activity (drta) terhadap sikap sosial dan kemampuan membaca pemahaman bahasa inggris siswa kelas viii smp dharma wiweka Denpasar. e-Journal Program Pascasarjana Universitas Pendidikan Ganesha Program Studi Pendidikan Dasar Volume 3.

Dantes, N. 2017. Desain Eksperimen dan Analisis Data. Depok: Rajawali Pers

Daryanto. 2014. Pendekatan Pembelajaran Saintifik Kurikulum 2013. Yogyakarta: Gava Media

Krismanto, Wawan, Abdul Khalik,Sayidiman. 2015. Meningkatkan kemampuan Membaca pemahaman Melalui metode survey,Question,Read,Recite,Review(SQ3R) Pada siswa kelas iv sd negeri 46 pare-pare. Jurnal Publikasi Pendidikan|Volume V No 3 September 2018)

Kurniawan, Heru. 2015. Pembelajaran Kreatif Bahasa Indonesia (Kurikulum 2013). Jakarta: Prenadamedia Group

Kusuma, Ida Bagus Indra, I Gusti Ngurah Japa, Made Sumantri. 2014. pengaruh strategi direct reading thinking activty (drta) terhadap keterampilan membaca pemahaman siswa. e-Journal MIMBAR PGSD Universitas Pendidikan Ganesha Jurusan PGSD Vol. 2 No. 1

Mujaddid, Faisal. 2016. Peningkatan Keterampilan Membaca Pemahaman Dengan Menggunakan Strategi DRTA (Directed Reading Thinking Activity) Pada Siswa Sekolah Dasar. Jurnal Didaktika Dwija Indria (Solo) Vol $\quad 4, \quad$ No $\quad 3 . \quad$ Tersedia pada http://jurnal.fkip.uns.ac.id/index.php/pgsdsolo/article/view/6889/6599. (diakses tanggal 17 Januari

Nasution, Efrizal. 2014. "Problematika Pendidikan di Indonesia". Jurnal Fakultas Ushuluddin dan Dakwah IAIN Ambon, Vol 8, No 1. Tersedia pada http://ejurnal.lp2miainambon.id/index.php/mediasi/article/view/261/221 (diakses tanggal 16 Januari 2018).

Rodiyah, Siti, Sri Joeda Andajani. 2016. penerapan strategi drta (directed reading thinking activity) dalam pembelajaran membaca pemahaman siswa tunarungu kelas VIII DI SLB. Jurnal Pendidikan Khusus Volume 8 Nomor 2.

Rofikasari, Fitri. 2016. Peningkatan Keterampilan Membaca Pemahaman Melalui Strategi Directed Reading Thinking Activity (Drta) Pada Siswa Kelas V SD Negeri 2 Jlegiwinangun Tahun Ajaran 2014/2015. Kalam Cendekia PGSD Kebumen, Volume 4, Nomor 1.1, (hlm. 11-16). Tersedia pada http://jurnal.fkip.uns.ac.id/index.php/pgsdkebumen/article/view/6751/5042 (diakses tanggal 16 Januari 2018)

Setyosari, Punaji. 2016. Metode Penelitian Pendidikan dan Pengembangan. Jakarta: Prenadamedia Grup

Sucitayana, I Made. 2014. Pengaruh Model DRTA Terhadap Keterampilan Membaca Pemahaman Literal Pada Mata Pelajaran Bahasa Indonesia Siswa Kelas V SD Negeri Gugus III Sukawati. Jurnal Mimbar PGSD Universitas Pendidikan Ganesha Vol: 2 No:1. Tersedia pada

https://ejournal.undiksha.ac.id/index.php/JJPGSD/article/view/3031 (diakses tanggal 17 Januari 2018)

Sugiono. 2017. Metode Penelitian Kuantitatif, Kualitatif dan R\&D. Bandung: Alfabeta

Susanto, Ahmad. 2014. Pengembangan Pembelajaran IPS di Sekolah Dasar. Jakarta: Prenasamedia Group 
Taufina. 2016a. Mozaik Keterampilan Berbahasa di Sekolah Dasar. Bandung: CV. Angkasa

Taufina dan Faisal. 2016b. Mozaik Penilaian Pembelajaran dan Apresiasi Sastra Indonesia di Sekolah Dasar. Cetakan ke-1. Bandung: CV. Angkasa 